\title{
DIAGNOSIS WITH DIFFERENT LEPTOSPIRA SEROVARS IN DOG
}

Guilherme Augusto Silvestre Ferreira ${ }^{1}$; Diego Carvalho Viana ${ }^{2^{*}}$, Leandro Almeida $\mathrm{Rui}^{2}$, Amilton Cesar dos Santos ${ }^{2}$, Gleidson Benevides de Oliveira ${ }^{3}$, Paulo Usignolo Carnauba Vicente ${ }^{4}$

${ }^{1}$ Academic course of Biological Sciences, University of São Judas Tadeu - Campus Mooca (USJT).

${ }^{2}$ Department of Surgery. Sector of Anatomy of Domestic and Wild Animals. School of Veterinary Medicine and Animal Science. Av. Prof. Dr. Orlando Marques de Paiva, 87, 05508-270. São Paulo, SP, Brasil.

${ }^{3}$ Federal Rural University of the Semi-Arid.

${ }^{4}$ Veterinary Medicine, FULLPET Clinic. Av. Jamil João Zarif, 888, 07143-000.

Guarulhos, SP, Brasil. *Correspondence to: Diego Carvalho Viana, E-mail: diego_carvalho_@hotmail.com. School of Veterinary Medicine and Animal Science.

Av. Prof. Dr. Orlando Marques de Paiva, 87, 05508-270. São Paulo, SP, Brasil.

Recebido em: 01/07/2015 - Aprovado em: 31/07/2015 - Publicado em: 21/08/2015

\begin{abstract}
Leptospirosis is an emerging disease, caused by a bacterium from genus Leptospira, which may presents different serotypes, and being transmitted mainly by sinantropics rodents. Have symptoms of acute onset, becoming a chronic disease as several organs are affected, causing various symptoms. In this case report, a dog under complait of anorexia, vomiting, prostration and melena was diagnosed with leptospirosis after positive serology for 7 distinct serotypes, and complete blood count (CBC) with severe leukocytosis and thrombocytopenia. Patient was treated with penicillin combined with streptomycin $40.000 \mathrm{IU} / \mathrm{kg}$ every 12 hours, along with supportive treatment with fluids, gastric protectors, antiemetics, antipyretics and nutritional support. After treatment, the animal presented restoration without risk of death during two weeks.
\end{abstract}

KEYWORDS: Infectious diseases, leptospirosis, serotypes, vaccination

\section{DIAGNÓSTICO COM DIFERENTES SOROVARES DE LEPTOSPIRA EM CÃO}

\section{RESUMO}

A leptospirose é uma doença emergente causada por uma bactéria do gênero Leptospira, podendo apresentar diversos sorovares, e sendo transmitida principalmente por roedores sinantrópicos. Tem sintomas de início agudo, podendo se tornar uma doença crônica conforme diversos órgãos são atingidos, causando diversos sintomas. Neste relato de caso, um cão sob queixa de anorexia, êmese, prostração e melena foi diagnosticado com leptospirose após sorologia positiva para 7 sorovares distintos e hemograma com intensa leucocitose e trombocitopenia. $\mathrm{O}$ tratamento realizado foi com penicilina associada à estreptomicina 40.000 Ul. $\mathrm{kg}^{-1} \mathrm{a}$ cada 12 horas, junto ao tratamento de suporte com fluidoterapia, protetores gástricos, antipiréticos e suporte nutricional. O animal logo após o tratamento 
durante duas semanas apresentou melhora sem risco de vida.

PALAVRAS-CHAVE: Doenças infecciosas, leptospirose, sorovares, vacinação

\section{INTRODUCTION}

Leptospirosis is an emerging zoonosis of global importance caused by bacteria from family Leptospiraceae, genus Leptospira, which is mainly transmitted by sinantropics rodents (Rattus norvegicus, Rattus rattus and Mus musculus) and other mammals infected (GIRIO et al., 2004). The dog, through contact with human is regarded as the most important domestic animal among the hosts of Leptospira (ABUCHAIM, 1986). Several serovars can infect the dog, but these may or not present clinical symptoms (HAGIWARA et al., 2004)

These bacteria remain in the urine of these animals, specially the rodents and penetrate in the host through the skin and mucous membranes (RENDE et al., 2007) of the human or domestic mammals as the dog. It can be caused by several types of serovars, often different strains protected by current vaccines.

Warm and humid climatic conditions favor a higher survival of leptospira in the environment, resulting in a higher incidence of leptospirosis in the summer and autumn (MAJOR et al., 2014). According to OLIVEIRA (1988), leptospirosis presents acute signs of disease from $3^{\text {rd }}$ to $14^{\text {th }}$ day after infection. RAMOS et al., (1981) adds that this disease can become chronic thereafter.

Onset of leptospirosis is sudden with headache, fever (usually $39^{\circ} \mathrm{C}$ ), malaise, myalgia, conjunctival suffusion and sometimes transient rash. Thereafter, the disease may be mild and self-limiting, or severe and fatal. The mild type may be disabling, but rarely leads to kidney or liver failure, bleeding or death (SUHELLA et al., 2010). Typical leptospirosis in dogs is characterized by fever, jaundice, vomiting, diarrhea, disseminated intravascular coagulation, uremia caused by renal failure, hemorrhage and death (BOLIN, 1996). This report evaluated different serovars groups of leptospirosis in a dog treated at a veterinary clinic.

\section{CASE REPORT}

A male dog race Pug, 8 months old and black, was analyzed at the veterinary clinic FULLPET in early August, São Paulo, Brazil. The animal lives in the home environment in Guarulhos, SP, at district Fortaleza without contactants and without proper annual vaccination, only with the pup vaccination. The animal has access to the external environment (street) every day in the morning. On clinical examination, was found as the main complaint anorexia, vomiting, prostration and melena and in the historic there was no reports about the vaccination or vermifugation, having the owner mentioned yet that the dog had contact with rodents. On physical examination revealed generalized jaundice, fever $\left(41.2^{\circ} \mathrm{C}\right)$, abdo minal pain, moderate dehydration evaluated with the skin turgidity. The haemogram showed thrombocytopenia and severe leukocytosis, plus jaundiced plasma. Clinical diagnosis associated with hematology tests and historical of non-vaccination guided suspicion. The animal was hospitalized for nine days and serology tests were requested.

By serological evaluation, there were seven different serotypes: Leptospira autumnalis, L. australis, L. castellonis, L. copenhageni, L. icterohaemorragiae, $L$. pyrogenes e $L$. sejroe. The animal was admitted and began treatment with intravenous fluids, use of antibiotics (penicillin-streptomycin associated $40.000 \mathrm{IU} . \mathrm{kg}$ 1 every 12 hours), support treatment with the use of gastric protectors (ranitidine 2 
mg.kg-1 every 12 hours, omeprazole $1 \mathrm{mg} \cdot \mathrm{kg}^{-1}$ every 24 hours and ondansetron 0.5 mg.kg-1 every 8 hours) and antipyretics (dipyrone $28 \mathrm{mg}^{\mathrm{kg}}{ }^{-1}$ every 8 hours as needed). Antibiotic therapy lasted 15 days, however after seven days, the animal showed clinical improvement, then after nine day it was released. The medication was associated with nutritional support (hypercaloric food Royal Canin Recovery by syringe administration). Immediately, after treatment, during two weeks, the animal showed improvement without risk of death.

\section{DISCUSSION}

Leptospirosis affects wild and domestic animals and human. Transmission occurs through contact with contaminated water by spirochetes that are eliminated in urine. Dogs can acquire the infection by living with other contaminated dogs and by contact with urine of rats in public areas. These animals can eliminate living leptospires in the urine for several months without presenting any clinical signs and are considered the main source of human leptospirosis in urban areas. To Leptospira survival in the environment it depends on humidity, high temperature or slightly alkaline $\mathrm{pH}$ (BLAZIUS et al., 2005).

Each serovar has one or more hosts with different levels of adaptation. In this case, serological evaluation was done for 19 serovars and 7 were positive, which may be considered a higher number, since it was only an infected animal. The serovars most commonly found in dogs are L. icterohaemorrahagiae and L. canicola. Also can be found $L$. copenhageni (FREIRE et al., 2007) and less frequently $L$. australis (VIEGAS et al., 2001), L. andamana, L. pyrogenes and L. autumnalis (BROD, 1996). However, have been reported increased occurrence of leptospirosis by serovars grippotyphosa, pomona, hardjo and Bratislava (WARD, 2002; MADRON et al., 2003).

For BOLIM et al., (1996), the incidence of infection by serovar L. canicola in unvaccinated populations of dogs may occur between 50 to $75 \%$ and appear as important source of infection for humans, but in this case it not found. In turn, the serovar $L$. icterohaemorrhagiae that has dogs as accidental hosts presents itself as the most severe forms of leptospirosis (TORTEN, 1979; BLAZIUS et al., 2005). In Southeast of Brazil the serovar $L$. icterohaemorragiae has become the most common (AVILA et al., 1980; FAVERO et al., 2002; FREIRE et al., 2007), probably due to the contact of the dogs with rodents or other stray dogs, contributing to the spread of canine leptospirosis, agreeing with FURTADO et al., (1997), which mentioned yet that the lack of public sewer and contact with contaminated water increase from 1.98 to 2.61 times the risk of infection to animals.

Leptospira enter through the body through small incisions in the mucous membranes or damaged skin. Then, it circulates in the bloodstream with leptospiremia phase lasting up to seven days. Numbers of Leptospira in the blood and tissues reach a critical level, causing injuries due to the action of toxin produced by infectious agent and the immune system and subsequent symptoms appear. Leptospira replicates in the renal tubular epithelium and can cause acute injury and renal failure; in the liver can damage hepatocytes resulting in acute liver necrosis, liver fibrosis and chronic active hepatitis (BICHARD \& SHERDING, 2003).

There are several clinical manifestations in dogs, which may or not include jaundice, depending on the infecting serovar. In the acute form can cause death of the animal by renal and hepatic impairment, occurring in this case hemorrhage, jaundice and thrombocytopenia (GENOVEZ, 2009; SUHELLA et al., 2010). It is 
reported by dogs by typical signs of leptospirose, $40{ }^{\circ} \mathrm{C}$ of body temperature, difficulty to move the hindquarters, apathy, anorexia, abdominal pain and hind limbs on palpation, bloody diarrhea, vomiting yellowish, bloody saliva, necrosis of tongue's edge and hematuria (CACCHIONE et al., 1962; BIRNBAUM et al., 1998; BROD et al., 2005).

When the animals survive, become asymptomatic carriers and excrete Leptospira in urine. The tissue damage, although severe is reversible and may be followed by complete repair, although the long term damage can lead to complications and well recognized scarring in the kidneys of dogs, in which may be macroscopically observed "white spots" (SUHELLA et al., 2010). It is noteworthy that in pregnant animals, after reaching the bloodstream or lymphatic chain, the Leptospira reach the uterus and the placenta at any stage of gestation and reaching the fetus causing death and its expulsion about 24 hours (GENOVEZ, 2009).

Regarding prevention, there are occupational hygiene measures, such as protective clothing and preventing splash of urine or water, but is difficult to implement, because they are not easily accepted by workers and employers. Generally, vaccines contain two or more prevalent serovars. As with natural infection, immunity is restricted to antigenically related serovars. In all cases, the biannual repeated revaccination is recommended to maintain immunity (MARTINEZ et al., 2004).

Commercial vaccines against leptospirosis are globally available for cattle, pigs and dogs, but have been shown only partially effect due to the fact of immunity induced by the vaccine is restricted to a serovar group. The most developed vaccines consist of whole cells containing Leptospira inactivated by chemical or warm heat process (WANG et al., 2007).

In North America the commercial vaccine also contains the serovars $L$. canicola, L. grippotyphosa and L. icterohaemorrhagiae. Vaccines generally protect against shedding and renal disease under experimental conditions, but serovars transmissions of $L$. icterohaemorrhagiae by immunized dogs to humans has been reported. Moreover, the immunized dogs could be infected by different serovars beyond those contained in commercial vaccines (PRESCOTT, 2008).

In this regard, have been reported the increased occurrence of leptospirosis by serovars grippotyphosa, pomona, hardjo and bratislava, but in these case, the serovars were not verified. The authors attributed this change to the absence of serotypes commonly used in vaccines (WARD, 2002; MADRON et al., 2003). WARD (2002) also suggests that the increased urbanization process and the contact of the dogs with reservoirs or the environment in which they live, increasing the exposure to these serotypes.

\section{CONCLUSION}

This report is important to characterize different serovars of leptospirosis, which allows control over the immunization status of patients and the prevention or treatment of disease. Among the serovars observed in the serological evaluation, $L$. icterohaemorrhagiae group was considered the more serious. We highlight vaccines as an important way of preventing disease, but are still required further studies to obtain greater efficiency. Thus, the treatment of symptoms can be effective as in the present case. 


\section{ACKNOWLEDGEMENTS}

To University of São Paulo (USP); to Foundation for Research Support of the State of Maranhão (FAPEMA); and to (CAPES) for grant this research.

\section{REFERENCES}

AVILA, F. A.; PINTO, G. C.; PECEGO, C. E. V.; SILVA JUNIOR, C. O. Frequência de aglutininas antileptospiras em cães no município de Jaboticabal, Brasil. In: Encontro de pesquisas veterinárias, 5., Jaboticabal. Anais... São Paulo, Sociedade Paulista de Medicina Veterinária, p. 68.1980.

ABUCHAIM, D. M. Comparação entre os resultados obtidos em cães suspeitos e assintomáticos no diagnóstico laboratorial da leptospirose. Arquivos da Faculdade Veterinária UFRGS, v. 14, p. 5-9, 1986.

BLAZIUS, R. D.; ROMÃO, P. R. T.; BLAZIUS, E. M. C. G. Ocorrência de cães errantes soropositivos para Leptospira spp. na cidade de Itapema, Santa Catarina, Brasil. Caderno de Saúde Pública, v. 21, p. 1952-1956, 2005.

BICHARD, S. J. B.; SHERDING, R. G. Manual Saunders - Clínica de Pequenos Animais. 2a. ed., Roca, p.148-150, 2003.

BIRNBAUM, N.; BARR, S. C.; CENTER, S. A.; SCHERMERHORN, T.; RANDOLPH, J. F.; SIMPSON, K. W. Naturally acquired leptospirosis in 36 dogs: serological and clinicopathological features. Journal of Small Animal Practice, v. 39, p. 231- 236, 1998.

BOLIN, C. A. Diagnosis of leptospirosis: a reemerging disease of companion animals. Seminars in veterinary medicine and surgery, v. 11, p. 166-171, 1996.

BROD, C. S. Fatores de Risco à Leptospirose canina no município de Pelotas, RS. In: Congresso Brasileiro de Medicina Veterinária, 24, Rio Grande do Sul. Anais... Rio Grande do Sul, Delcione Silveira, p. 137.1996.

BROD, C. S.; ALEIXO, J. A. G.; JOUGLARD, S. D. D.; PINHO, C.; FERNANDES, H.; TEIXEIRA, J. L. R.; DELLAGOSTIN, O. A. Evidência do cão como reservatório da leptospirose humana: isolamento de um sorovar, caracterização molecular e utilização em inquérito sorológico. Revista da Sociedade Brasileira de Medicina Tropical, v. 38, n. 4, p. 294-300, 2005.

CACCHIONE, R. A.; CEDRO, V. C. F.; BULGINI, M. J. D.; CASCELLI, E. S.; MARTINEZ, E. S. Leptospirosis canina en la Republica Argentina. Revista de Investigación Ganadera, v. 14, p. 125-132, 1962.

FAVERO, A. C. M.; PINHEIRO, S. R.; VASCONCELLOS, S. A.; MORAIS, Z. M.; FERREIRA, F.; NETO, J. S. F. Sorovares de leptospiras predominantes em exames sorológicos de bubalinos, ovinos, caprinos, eqüinos, suínos e cães de diversos estados brasileiros. Ciência Rural, v. 32, n. 4, p. 613-619, 2002. 
FREIRE, I. M. A.; VARGES, R. G.; GOMES, Y. N. P.; POMBO, C. R.; LILENBAUM, W. Distribuição dos serovares de leptospira em caninos clinicamente suspeitos no Rio de Janeiro. Revista Brasileira de Ciências Veterinárias, v. 14, n. 2, p. 83-85, 2007.

FURTADO, L. R. I.; FEHLBERG, M. F. B.; AVILA, M. O.; TEIXEIRA, M. M.; ROSADO, R. L. I.; MARTINS, L. F. S.; BROO, C. S. Prevalência e avaliação de fatores de risco à leptospirose canina, no município de Pelotas, RS. Arquivo do Instituto de Biologia, v. 64, n. 1, p. 57-61, 1997.

GENOVEZ, M. E. Leptospirose: uma doença de ocorrência além da época das chuvas. O Biológico, v. 71, n.1, p. 1-3, 2009.

GIRIO, R. J. S.; PEREIRA, F. L. G.; MARCHIORI FILHO, M.; MATHIAS, L. A.; HERREIRA, R. C. P.; ALESSI, A. C.; GIRIO, T. M. S. Pesquisa de anticorpos contra Leptospira spp. em animais silvestres e em estado feral da região de Nhecolândia, Mato Grosso do Sul, Brasil: utilização da técnica de imuno-histoquímica para detecção do agente. Ciência Rural, v. 34, p. 165-169, 2004.

HAGIWARA, M. K.; LUSTOSA, M.; KOGIKA, M. M. Leptospirose canina. Vet News, v. 11, n. 67, p. 7-8, 2004.

MADRON, E.; CHEUICHE, A. J. V. Eight cases of canine leptospirosis. A Hora Veterinária, v. 23, n. 135, p. 59-62, 2003.

MAJOR, A.; SCHWEIGHAUSER, A.; FRANCEY, T. Increasing Incidence of canine Leptospirosis in Switzerland. International Journal of Environmental Research and Public Health, v. 11, p. 7242-7260, 2014.

MARTÍNEZ, R.; PÉREZ, A.; QUIÑONES, C. M. Efficacy and safety of a vaccine against human leptospirosis in Cuba. Revista Panamericana de Salud Pública, v. 15, p. 249-255, 2004.

OLIVEIRA, S. J. Leptospirose em Suínos. A Hora Veterinária, v. 41, p. 5-8, 1988.

PRESCOTT, J. Canine leptospirosis in Canada: a veterinarian's perspective. Canadian Medical Association Journal, v. 178, p. 397-398, 2008.

RAMOS, A. A.; CORDEIRO, F.; GUIDA, H. G. Inquérito sociológico de leptospirose em suínos no Estado do Rio de Janeiro e região limítrofe. Pesquisa Veterinária Brasileira, v. 1, p. 81-83, 1981.

RENDE, J. C.; RIGOBELO, E. C.; MARIN, J. M. Infecção experimental em suínos jovens com Leptospira interrogans sorovar wolffi: determinação de parâmetros bioquímicos. Ciência Rural, v. 37, p. 458-463, 2007. 
SUHELLA, M. T.; SCOTT, B. C.; GLENN, C. G. Leptospira and leptospirosis. Veterinary Microbiology, v. 140, n. 3-4, p. 287-296, 2010.

TORTEN, M. Leptospirosis. In: STOENNER, H. E.; TORTEN, M.; KAPLAN W. (eds) CRC handbook series in zoonoses, section A: bacterial, rickettsial and mycotic diseases. CRC Press, Flórida, vol. I, p. 363-420, 1979.

VIEGAS, S. A. R. A.; TAVARES, C. H. T.; OliveIRA, E. M. D.; DIAS, A. R.; MENDONÇA F. F.; SANTOS, M. F. P. Investigação sorológica para leptospirose em cães errantes na cidade de Salvador - Bahia. Revista Brasileira de Saúde e Produção Animal, v. 2, n. 1, p. 21-30, 2001.

WANG, Z.; JIN, L.; WEGRZYN, A. Leptospirosis vaccines. Microbial Cell Factories, v. 6, p. 1-10, 2007.

WARD, M. P. Seasonality of canine leptospirosis in the United States and Canada and its association with rainfall. Prevent Veterinary Medicine, v. 56, n. 3, p. 203213, 2002 